\title{
Preliminary Report on Blending Strategies for Inert-Matrix Fuel Recycling in LWRs
}

Standard Report Cover

Nuclear Engineering Division Argonne National Laboratory 


\section{Preliminary Report on Blending Strategies for Inert-Matrix Fuel Recycling in LWRs}

by

Edward A. Hoffman

Nuclear Engineering Division

Argonne National Laboratory

March 31, 2005 


\section{About Argonne National Laboratory}

Argonne is operated by The University of Chicago for the U.S. Department of Energy Office of Science, under contract W-31-109-Eng-38. The Laboratory's main facility is outside Chicago, at 9700 South Cass Avenue, Argonne, Illinois 60439. For information about Argonne and its pioneering science and technology programs, see www.anl.gov.

\section{Availability of This Report}

This report is available, at no cost, at http://www.osti.gov/bridge. It is also available on paper to U.S. Department of Energy and its contractors, for a processing fee, from:

U.S. Department of Energy

Office of Scientific and Technical Information

P.O. Box 62

Oak Ridge, TN 37831-0062

phone (865) 576-8401

fax (865) 576-5728

reports@adonis.osti.gov

\section{Disclaimer}

This report was prepared as an account of work sponsored by an agency of the United States Government. Neither the United States Government nor any agency thereof, nor The University of Chicago, nor any of their employees or officers, makes any warranty, express or implied, or assumes any legal liability or responsibility for the accuracy, completeness, or usefulness of any information, apparatus, product, or process disclosed, or represents that its use would not infringe privately owned rights. Reference herein to any specific commercial product, process, or service by trade name, trademark, manufacturer, or otherwise, does not necessarily constitute or imply its endorsement, recommendation, or favoring by the United States Government or any agency thereof, Argonne National Laboratory, or The University of Chicago. 
(This page intentionally left blank) 


\section{PRELIMINARY REPORT ON BLENDING STRATEGIES FOR INERT-MATRIX FUEL RECYCLING IN LWRS}

\section{INTRODUCTION}

Various recycle strategies have been proposed to manage the inventory of transuranics in commercial spent nuclear fuel (CSNF), with a particular goal of increasing the loading capacity of spent fuel and reprocessing wastes in the Yucca Mountain repository. Transuranic recycling in commercial LWRs can be seen as a viable means of slowing the accumulation of transuranics in the nationwide CSNF stockpile. Furthermore, this type of approach is an important first step in demonstrating the benefits of a nuclear fuel cycle which incorporates recycling, such as envisioned for Generation-IV reactor systems under development. Recycling strategies of this sort are not proposed as an attempt to eliminate the need of a geologic nuclear waste repository, but as a means to enhance the usefulness of the repository currently under construction in the U.S., perhaps circumventing the need for a second facility. A US-DOE Secretarial recommendation on the need for the construction of a second geologic repository is required by 2010.

The Advanced Fuel Cycle Initiative (AFCI) has supported a breadth of work to evaluate the ideal transuranic separation and recycle strategy. Previous AFCI studies of LWR-based transmutation have considered the benefits of homogeneously recycling plutonium, plutonium and neptunium, and all transuranic (TRU) species. ${ }^{1,2,3,4}$ A study of a wide range of hypothetical separation schemes $(\mathrm{Pu}, \mathrm{Pu}+\mathrm{Np}, \mathrm{Pu}+\mathrm{Np}+\mathrm{Am}$, etc.) with multi-recycling has also been performed, focusing on the proliferation resistance of the various fuel cycles and fuel handling issues. ${ }^{5}$

The direct recycle of the recovered TRU from spent inert-matrix fuel (IMF) into new IMF was found to be quite limited due to the rapid burndown of the fissile plutonium. The IMF is very effective at destroying the fissile fraction of the TRU with destruction rates in excess of $80 \%$ of the fissile material without recycling the IMF. Blending strategies have been proposed to mitigate the rapid burndown of the fissile plutonium by mixing high fissile feed from new sources (e.g., spent $\mathrm{UO}_{2}$ pins) with the low fissile material recovered from the recycled transmutation fuel. The blending of the fuels is anticipated to aid the multi-recycle of the transuranics. A systematic study of blending strategies (for both IMF and MOX) has been initiated and is currently ongoing.

This work extends the previous study that considered separation strategies for plutonium, neptunium, and americium recycling in MOX, CORAIL, and IMF $^{6}$ by considering blending schemes and approach to continuous recycle. Plutonium and americium are recycled in order to reduce the intermediate term (100 to 1500 years after spent fuel irradiation) decay heat of the disposed waste which accounts for the bulk of the repository heating. Since the long-term released dose from the repository is dominated by neptunium, it is sensible to consume it by transmutation in a reactor, as well. Curium accounts for $\sim 0.6 \%$ of the TRU mass in spent $\mathrm{UO}_{2}$ fuel $(\sim 0.008 \%$ of the heavy metal), but does constitute significantly higher fractions in spent transmutation fuels. This initial evaluation will focus on blending strategies for the multirecycling of $\mathrm{Pu}+\mathrm{Np}+\mathrm{Am}$. The impact of curium recycle will be investigated as part of the systematic study of blending strategies.

The initial study focuses on understanding a simple strategy for IMF recycle and blending. More complex strategies (i.e., heterogeneous assemblies) will be evaluated later in the year, 
including enriched uranium support options. Currently, a preliminary study of a serial blending strategy has been performed in order to evaluate the impact of blending on the performance of the IMF recycle and to evaluate the potential for continuous or infinite recycle. The continuous recycle of $\mathrm{Pu}+\mathrm{Np}+\mathrm{Am}$ in IMF would allow for complete destruction of all heat contributing actinides in the same LWRs that originally produced them. The only transuranics sent to the repository would be those lost in reprocessing and curium if it is not eventually recycled.

A serial blending in homogenous assemblies (all IMF pins with the same initial composition) provides a straightforward methodology to project to an equilibrium system comprised solely of $\mathrm{UO}_{2}$ fuel and IMF. For a limited recycle, the approach would allow for a tailored composition that may improve the performance of recycled IMF beyond that of direct recycle. The particular serial blending strategy considered used a variable blending ratio (fraction of TRU mass recovered from spent $\mathrm{UO}_{2}$ fuel relative to total TRU mass in fresh IMF), which leads to an equilibrium blending ratio for a fixed TRU feed stream from spent $\mathrm{UO}_{2}$ fuel. For example, the blending ratio for the Generation 1 IMF is calculated in equation 1 (data from Table 3).

$$
B R_{1}=\frac{M_{T R U_{\mathrm{UO}_{2}} \rightarrow T R U_{I M F}}^{1}}{M_{\mathrm{TRU}_{\mathrm{UO}_{2}}^{1} \rightarrow T R U_{\mathrm{MF}}^{1}}^{1}+M_{T R U_{\mathrm{MF}}^{0} \rightarrow T R U_{\mathrm{IMF}}^{1}}^{1}}=\frac{12,803 g}{12,803 g+5,234 g}=0.71,
$$

Blending ratios of zero (direct recycle), 0.71 (this report), and 1.0 (Generation 0 IMF) for the first recycle of IMF have been evaluated. Other blending ratios will be evaluated in the future to study their impact on a limited multi-recycle strategy.

The primary measure of effectiveness will be the decay heat based repository loading benefit. ${ }^{6}$ The repository benefit was evaluated for the equilibrium recycle and a finite number of recycles using the serial blending approach, with disposal of the material not consumed at the end of the recycling campaign.

Evaluations of the serial blending approach considered in this study for transuranic management are discussed in Section II. The performance measures (estimated temperatureconstrained repository loading) of the various homogeneous recycling scenarios are compared in Section III. Lastly, the preliminary conclusions based on current results are given in Section IV. 


\section{EVALUATIONS OF TRANSURANIC RECYCLING APPROACHES IN LWRS}

In this study, it was assumed that the recycled material originated from spent $\mathrm{UO}_{2}$ irradiated in a commercial PWR. The plutonium, neptunium, and americium were assumed to be recycled in a similar system a finite number of times, using an IMF assembly. The results were used to project the isotopic composition and loading for an infinite recycle using IMF. The isotopic vector of $\mathrm{Pu}+\mathrm{Np}+\mathrm{Am}$ in the charged assembly in recycle $\mathrm{N}$ was derived from discharged assemblies in recycle $\mathrm{N}-1$ blended with the $\mathrm{Pu}+\mathrm{Np}+\mathrm{Am}$ from spent $\mathrm{UO}_{2}$ fuel. Previous studies did not consider blending of recycled and reactor-grade (from spent $\mathrm{UO}_{2}$ ) TRU; however, that approach is the most straightforward and predicts the maximum benefit achievable for a given number of recycles. The results of that studied suggested a very limited number of recycle were possible using IMF; perhaps only two. Blending should increase the number of recycles by supplying fissile material and may possibly allow for infinite recycle.

In the IMF cases, the mass of TRU charged in the fresh recycled assembly was adjusted to meet the same operational requirements (full-power days of irradiation) in each recycle. The definition of a recycle is different than direct recycles. In each "recycle" some quantity of spent $\mathrm{UO}_{2}$ fuel and spent IMF is reprocessed, which is referred to as a generation. For this study, the quantity of $\mathrm{UO}_{2}$ reprocessed in each generation is assumed to be fixed. Generation 0 being the first recycle of spent $\mathrm{UO}_{2}$ fuel only. Generation 1 being the second recycle, which consists of reprocessing spent Generation $0 \mathrm{IMF}$ and the same quantity of spent $\mathrm{UO}_{2}$ fuel reprocessed in Generation 0. Consequently, the mass of spent fuel processed to produce a given mass of fresh IMF varied from one recycle to the next. The spent assembly from the $\mathrm{N}^{\text {th }}$ recycle (Generation $\mathrm{N}+1$ ) was assumed to be sent directly to the waste stream. Additionally, the non-recycled minor actinides (curium), the reprocessing waste stream (assumed to be $0.1 \%$ of the $\mathrm{Np}+\mathrm{Pu}+\mathrm{Am}$ at each stage), and fission products from each recycle stage (cesium and strontium were removed) were assumed to be disposed in the repository.

This section first provides a description of the neutronics and mass flow analyses which were performed for this study (sub-section II.1). Reactor safety considerations arising from the utilization of transuranic-bearing fuels in existing LWRs are briefly addressed in sub-section II.2. Lastly, sub-section II.3 provides fuel cycle data for a nuclear enterprise fueled with $\mathrm{UO}_{2}$ and recycled fuel operating in an equilibrium mode.

\section{II.1. Neutronics and Mass Flow Analyses}

Assembly-level calculations were performed assuming a typical 17x17 PWR $\left(\mathrm{UO}_{2}\right)$ assembly design, with only substitution of the fuel form in the recycled assemblies (i.e., IMF fuel pins). Assembly design parameters for $\mathrm{UO}_{2}$, and IMF assemblies are summarized in Table 1.

For the IMF cases, the heavy metal loading is significantly lower in the first recycle due to the utilization of a non-uranium matrix (factor of 10). With each successive recycle of the unconsumed material, however, the heavy metal (transuranic) loading must be increased to compensate for the reduction of the fissile fraction in the material and to maintain the irradiation cycle length. Consequently, it was necessary to recalculate certain parameters (e.g., fuel density, specific power) needed for the neutronics analysis for each recycle. 
Table 1. UO $\mathbf{O}_{2}$ and Inert Matrix Fuel Assembly Design Parameters.

\begin{tabular}{|c|c|c|}
\hline & $\mathrm{UO}_{2}$ & IMF \\
\hline Assembly size & $17 \times 17$ pins & $17 \times 17$ pins \\
\hline Number of fuel pins & 264 & 264 \\
\hline Number of guide tubes (GT) & 24 & 24 \\
\hline $\begin{array}{l}\text { Number of instrumentation tubes } \\
\text { (IT) }\end{array}$ & 1 & 1 \\
\hline Fuel rod pitch $(\mathrm{cm})$ & 1.2598 & 1.2598 \\
\hline Inter-assembly gap $(\mathrm{cm})$ & 0.08 & 0.08 \\
\hline Fuel pellet material & $\mathrm{UO}_{2}$ & Solid solution ( $\mathrm{Zr}, \mathrm{TRU}) \mathrm{O}_{2}$ \\
\hline $\mathrm{ZrO}_{2}$ hole $^{1}$ radius $(\mathrm{cm})$ & N/A & $\begin{array}{l}0.2048\left(1^{\text {st }} \text { recycle }\right) \\
0.1930\left(2^{\text {nd }} \text { recycle }\right) \\
0.0929 \text { (eq. recycle) }\end{array}$ \\
\hline Fuel pellet radius $(\mathrm{cm})$ & 0.4096 & 0.4096 \\
\hline Clad inner radius $(\mathrm{cm})$ & 0.4178 & 0.4178 \\
\hline Clad outer radius $(\mathrm{cm})$ & 0.4750 & 0.4750 \\
\hline $\begin{array}{l}\text { Smeared fuel density }\left(\mathrm{g} / \mathrm{cm}^{3}\right) \\
\text { (pellet at } 95 \% \text { T.D., } 1.2 \% \text { pellet } \\
\text { dishing) }\end{array}$ & 9.88 & $\begin{array}{l}5.60\left(1^{\text {st }} \text { recycle }\right) \\
6.00\left(2^{\text {nd }} \text { recycle }\right) \\
8.70(\text { eq. recycle })\end{array}$ \\
\hline Fuel mass (kg HM/assembly) & 461.3 & $\begin{array}{l}42.1\left(1^{\text {st }} \text { recycle }\right) \\
64.3\left(2^{\text {nd }} \text { recycle }\right) \\
310.0(\text { eq. recycle })\end{array}$ \\
\hline Zircaloy-4 clad density $\left(\mathrm{g} / \mathrm{cm}^{3}\right)$ & 6.5 & 6.5 \\
\hline GT/IT inner radius $(\mathrm{cm})$ & 0.5715 & 0.5715 \\
\hline GT/IT outer radius $(\mathrm{cm})$ & 0.6121 & 0.6121 \\
\hline $\begin{array}{l}\text { Specific power density } \\
(\mathrm{MW} / \mathrm{MTHM})\end{array}$ & $33.69^{2}$ & $\begin{array}{c}368.9^{2}\left(1^{\text {st }} \text { recycle }\right) \\
201.9\left(2^{\text {nd }} \text { recycle }\right) \\
48.3\left(3^{\text {rd }} \text { recycle }\right)\end{array}$ \\
\hline Discharge burnup (GWd/MTHM) & 50 & $\begin{array}{c}553\left(1^{\text {st }} \text { recycle }\right) \\
303\left(2^{\text {nd }} \text { recycle }\right) \\
72\left(3^{\text {rd }} \text { recycle }\right)\end{array}$ \\
\hline Fuel temperature $\left({ }^{\circ} \mathrm{K}\right)$ & 900.0 & 900.0 \\
\hline Cladding temperature $\left({ }^{\circ} \mathrm{K}\right)$ & 581.0 & 581.0 \\
\hline Bulk coolant temperature $\left({ }^{\circ} \mathrm{K}\right)$ & 581.0 & 581.0 \\
\hline Nominal coolant density $\left(\mathrm{g} / \mathrm{cm}^{3}\right)$ & 0.72 & 0.72 \\
\hline
\end{tabular}

As in previous evaluations of transuranic recycling in LWRs, the WIMS8 ${ }^{7}$ code was utilized for the mass flow analyses. The 172-group, JEF2.2-based cross section library has been previously determined to provide accurate modeling of the important $\mathrm{Pu}-239, \mathrm{Pu}-240$, and $\mathrm{Pu}-$ 241 resonances. One-eighth-symmetric assembly calculations with reflective boundary conditions were performed, simulating a full-core loading of the $\mathrm{UO}_{2}$, or IMF assembly. A linear reactivity letdown model and three-batch irradiation to the discharge burnup were assumed. Consequently, assuming a core neutron leakage of $3.5 \% \Delta \mathrm{k}$, the critical core end-of-cycle condition was approximated by an assembly calculation at $2 / 3$ of the discharge burnup with $\mathrm{k}_{\infty}=1.035$. The transuranic feed material for the IMF fuel was assumed harvested from $\mathrm{UO}_{2}$ which had been enriched to $4.2 \mathrm{wt} . \% \mathrm{U}-235$, irradiated to $50 \mathrm{GWd} / \mathrm{MT}$, and cooled for 5 years. The isotopic vector for the recycled transuranics is provided in Table 2. 
The $\mathrm{Pu}+\mathrm{Np}+\mathrm{Am}$ stream was used to fabricate the recycle fuel, with a two-year postfabrication interval occurring before charge into the reactor. The length of this interval is somewhat important, as ongoing decay of $\mathrm{Pu}-241\left(\mathrm{t}_{1 / 2}=14.4\right.$ years $)$ to Am-241 reduces the fissile content before irradiation begins, and requires a higher transuranic loading in the fabricated fuel to meet the irradiation cycle requirements. For the IMF case, the fuel discharge burnup was allowed to vary with each recycle as the heavy metal loading per assembly was adjusted (see Table 1). Rather than fix the discharge burnup, it was appropriate to fix the irradiation cycle length at 500 days, which gave a total irradiation period of 1,500 full-power days.

Table 2. Plutonium, Neptunium, and Americium Isotopic Vector in Spent $\mathrm{UO}_{2}$ (50 GWd/MT).

\begin{tabular}{|l|c|c|}
\hline \multirow{2}{*}{} & \multicolumn{2}{|c|}{ Number of Years Cooled } \\
\cline { 2 - 3 } & $\mathbf{5}$ Years & $\begin{array}{c}\text { 2 Years } \\
\text { (post fabrication) }\end{array}$ \\
\hline $\mathrm{Am} 241$ & $3.416 \%$ & $4.396 \%$ \\
\hline $\mathrm{Am} 242 \mathrm{~m}$ & $0.006 \%$ & $0.006 \%$ \\
\hline $\mathrm{Am} 243$ & $1.529 \%$ & $1.529 \%$ \\
\hline $\mathrm{Np} 237$ & $4.750 \%$ & $4.765 \%$ \\
\hline $\mathrm{Pu} 238$ & $2.336 \%$ & $2.301 \%$ \\
\hline $\mathrm{Pu} 239$ & $48.082 \%$ & $48.101 \%$ \\
\hline $\mathrm{Pu} 240$ & $22.395 \%$ & $22.400 \%$ \\
\hline Pu241 & $10.792 \%$ & $9.806 \%$ \\
\hline Pu242 & $6.693 \%$ & $6.696 \%$ \\
\hline
\end{tabular}

\section{II.1.a. IMF Recycling Campaign}

The impact of recycling the $\mathrm{Pu}+\mathrm{Np}+\mathrm{Am}$ in an inert-matrix fuel (IMF) form was considered. The inert-matrix fuel form considered here was solid-solution $(\mathrm{Zr}, \mathrm{Pu}, \mathrm{Np}, \mathrm{Am}) \mathrm{O}_{2}$. Due to the lower thermal conductivity of the zirconia relative to typical $\mathrm{MOX}$ or $\mathrm{UO}_{2}$, an annular fuel pellet design was assumed so that the fuel centerline temperature would be within a reasonable limit. ${ }^{8}$

Without fertile U-238 in the inert-matrix fuel, transmutation will change the isotopic mix of transuranics, but additional transuranics are not produced during irradiation and a significant net consumption of the transuranic material is achieved. Inert-matrix fuels were initially envisioned as part of the weapons-material disposition program, as they target the consumption of Pu-239. However, this characteristic of IMF will actually limit its potential benefit to the repository since the number of recycles will be constrained by the declining reactivity of the recycled material. This is the reason for evaluating blending strategies to maintain the reactivity of the recycled fuel and allow for a greater number of recycles and evaluate the potential for an infinite recycle. If a constant irradiation cycle length is to be maintained, it is likely that only a few recycles will be possible without blending or other types of reactivity support.

The transuranic mass in the first recycle IMF case is $42.1 \mathrm{~kg} /$ assembly. Previous studies have evaluated the direct recycle (without blending) of this material as shown in Figure 1. If this fuel is directly recycled, the assembly loading required to meet reactivity limits for the first generation of recycled IMF would require $308 \mathrm{~kg} /$ assembly (Figure 4) and the second generation 
of recycled IMF would be unable to achieve the desired cycle length with TRU-O $\mathrm{O}_{2}$ fuel. Figure 1 shows the mass flow for one metric tonne initial heavy metal of $\mathrm{UO}_{2}$ fuel in a direct recycle system. The direct recycle of IMF would reduce the TRU with each subsequent recycle. However to achieve sufficient reactivity, the TRU loading must be increased substantially which reduces the fractional burnup achieved in each subsequent generation. With a fixed assembly power and fuel residence time, the fractional burnup is inversely proportional to the heavy metal loading.

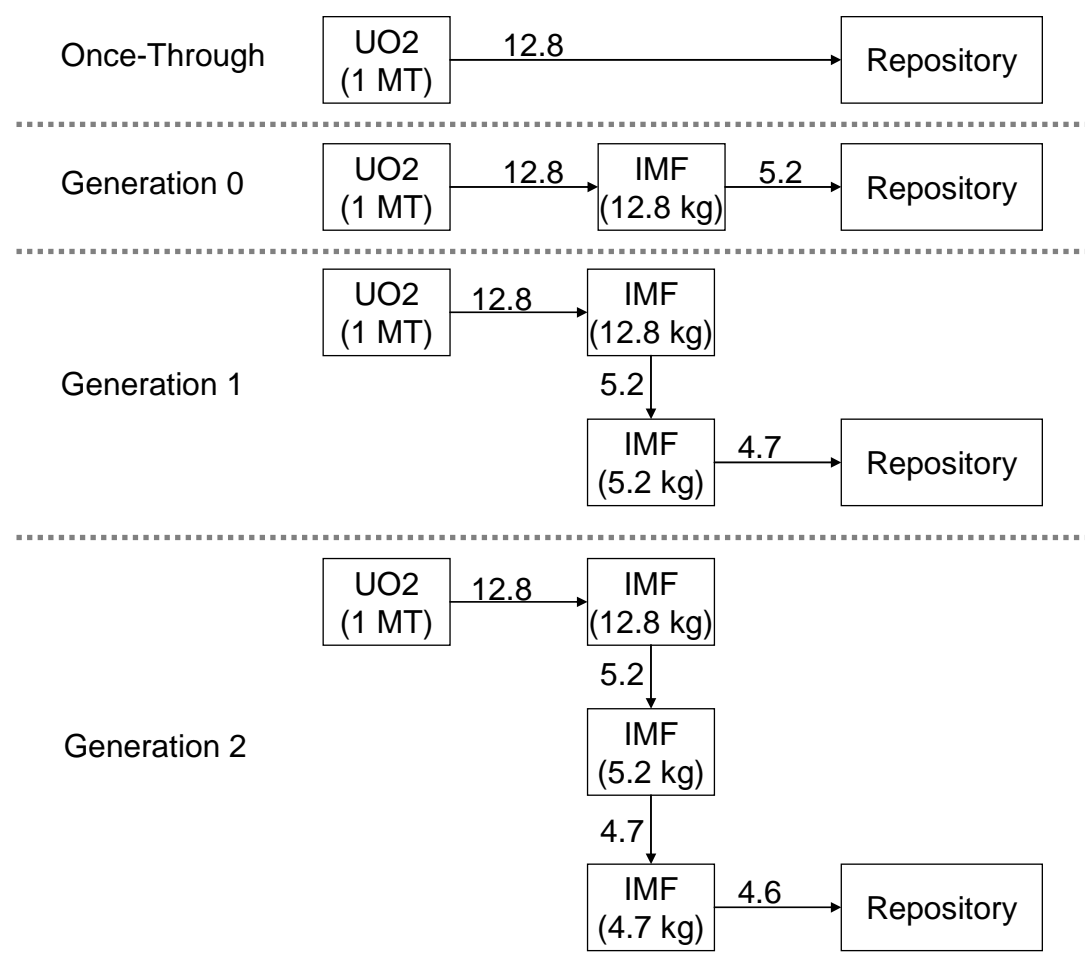

Figure 1. Direct Recycle of Transuranics in Homogeneous IMF Assembly. Values show mass in $\mathrm{kg}$ of recovered TRU. Losses and other unrecovered material are not shown.

A serial blending strategy was evaluated to attempt to improve the performance of the IMF recycle. Figure 2 shows the mass flow for a constant level (1 MTIHM per generation) of $\mathrm{UO}_{2}$. The serial blending results in a growing inventory of TRU as the residual inventory from the previous generation is added to the new TRU from spent $\mathrm{UO}_{2}$ fuel. This approach would ultimately lead to equilibrium conditions, where the TRU consumed equals the TRU recovered from spent $\mathrm{UO}_{2}$ fuel. The composition of the equilibrium cycle feed was estimated based on an isotopic-level extrapolation of the calculated values. The fresh fuel produced from the recycle of the extrapolated equilibrium fuel is nearly the same as the original fuel based on the extrapolated composition. The isotopic concentrations vary by less than $10 \%$ with most only varying by a few percent or less and the total TRU varied by less than one percent. This suggests that this fuel is representative of the true equilibrium fuel. 


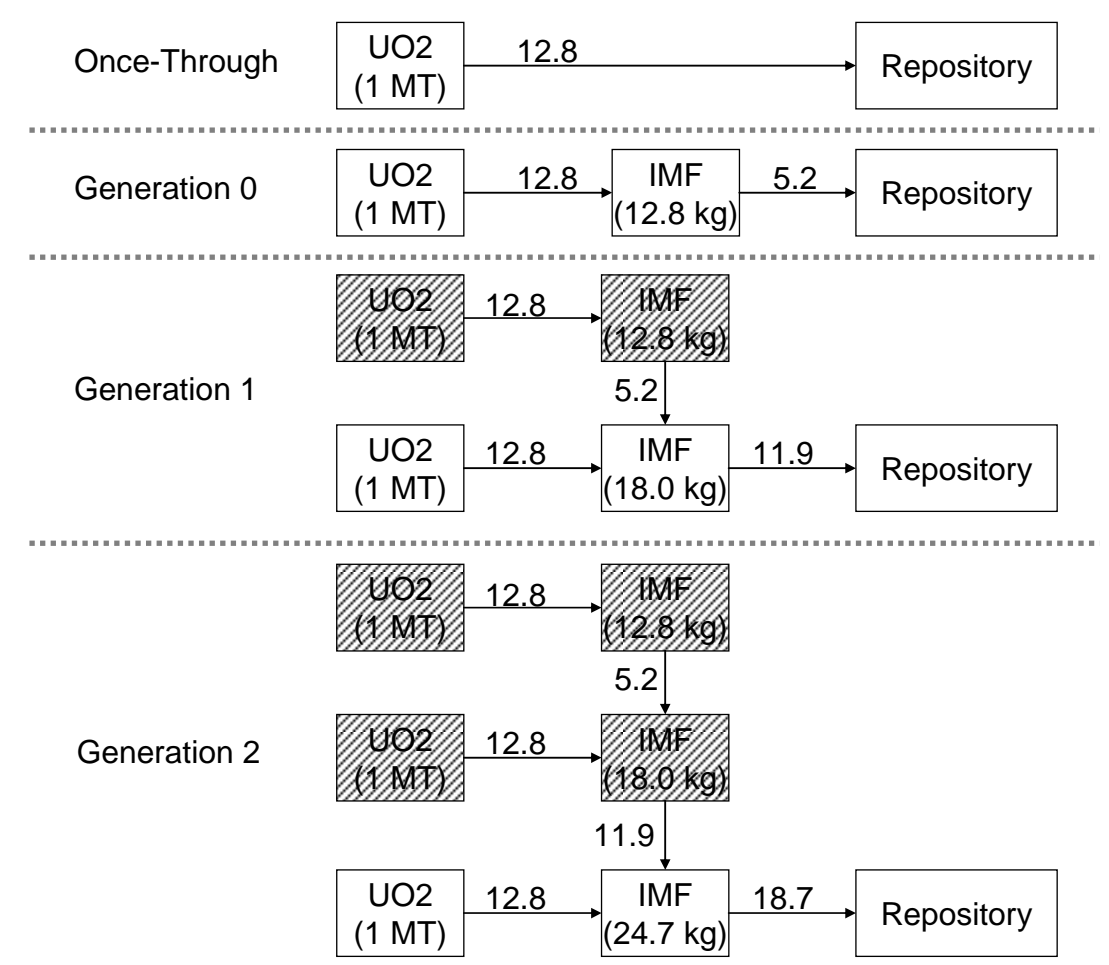

Figure 2. Serial Blending of Transuranics in Homogeneous IMF Assembly. Values show mass in $\mathrm{kg}$ of recovered TRU. Losses and other unrecovered material are not shown.

Table 3 shows the mass flow of TRU through the ten generations (eleven recycles) that were evaluated and the projected equilibrium. The direct recycle of the Generation 0 spent IMF and once-through cycle (OTC) values are included in Table 3 for comparison. The total TRU discharged to the waste stream is the sum of all TRU waste from the preceding generations and the TRU in the spent fuel if no further recycles were completed. The same would be true for the fission products. The results show the accumulation of TRU in each subsequent generation of the IMF. Even after ten generations, the resulting feed for the next generation is still far from equilibrium with the isotopic composition still changing significantly. Figure 3 shows the isotopic composition of the feed. Serial blending would result in a very slow approach to equilibrium and is clearly not the method that would be used as the approach to equilibrium recycle of IMF. Other strategies would allow for a much quicker approach to equilibrium, but will not be explored until other means to provide fissile support (e.g,. heterogeneous assemblies with enriched $\mathrm{UO}_{2}$ ) are also considered. 
Table 3. Transuranic Flow Rate for Serial Blending Strategy.

\begin{tabular}{|c|c|c|c|c|c|}
\hline $\begin{array}{c}\text { IMF Generation } \\
\text { I (\# recycles) }\end{array}$ & $\begin{array}{c}\text { LWR TRU } \\
\text { Feed }^{1} \\
\text { (g) }\end{array}$ & $\begin{array}{c}\text { Total TRU } \\
\text { Feed }^{1} \\
(\mathbf{g})\end{array}$ & $\begin{array}{c}\text { TRU } \\
\text { Discharge }^{2} \\
\text { (g) }\end{array}$ & $\begin{array}{c}\text { TRU } \\
\text { Recycle }^{1} \\
\text { (g) }\end{array}$ & $\begin{array}{c}\text { TRU } \\
\text { Waste }^{3} \\
\text { (g) }\end{array}$ \\
\hline OTC & 0 & 0 & 12,892 & 12,803 & 89 \\
\hline $0(\mathrm{~N}=1)$ & 12,803 & 12,803 & 5,576 & 5,234 & 342 \\
\hline $1(\mathrm{~N}=2)$ & 12,803 & 18,037 & 12,386 & 11,930 & 455 \\
\hline $2(\mathrm{~N}=3)$ & 12,803 & 24,733 & 19,184 & 18,667 & 517 \\
\hline $3(\mathrm{~N}=4)$ & 12,803 & 31,470 & 25,492 & 24,909 & 583 \\
\hline $4(N=5)$ & 12,803 & 37,712 & 31,327 & 30,683 & 644 \\
\hline $5(\mathrm{~N}=6)$ & 12,803 & 43,485 & 36,726 & 36,026 & 700 \\
\hline $6(N=7)$ & 12,803 & 48,828 & 41,714 & 40,962 & 752 \\
\hline $7(\mathrm{~N}=8)$ & 12,803 & 53,763 & 46,332 & 45,532 & 799 \\
\hline $8(\mathrm{~N}=9)$ & 12,803 & 58,339 & 50,625 & 49,782 & 843 \\
\hline $9(\mathrm{~N}=10)$ & 12,803 & 62,585 & 54,605 & 53,720 & 885 \\
\hline $10(\mathrm{~N}=11)$ & 12,803 & 66,519 & 58,302 & 57,379 & 923 \\
\hline Equilibrium & 12,803 & 122,854 & 112,572 & 111,087 & 1,484 \\
\hline G0 IMF (N=1) & 12,803 & 12,803 & 5,576 & 5,234 & 342 \\
\hline Direct Recycle $(\mathrm{N}=2)$ & 0 & 5,234 & 4,819 & 4,743 & 76 \\
\hline
\end{tabular}

${ }^{1}$ Feed is based on recycle of $99.9 \%$ of $\mathrm{Np}, \mathrm{Pu}$, and $\mathrm{Am}$ recovered from spent $\mathrm{UO}_{2}$ fuel and IMF.

${ }^{2}$ Discharge is at 5 years post irradiation cooling time.

${ }^{2}$ Waste is $0.1 \%$ of $\mathrm{Np}, \mathrm{Pu}$, and $\mathrm{Am}$ not recovered from spent fuel plus $100 \%$ of $\mathrm{Cm}, \mathrm{Bk}$, and $\mathrm{Cf}$.

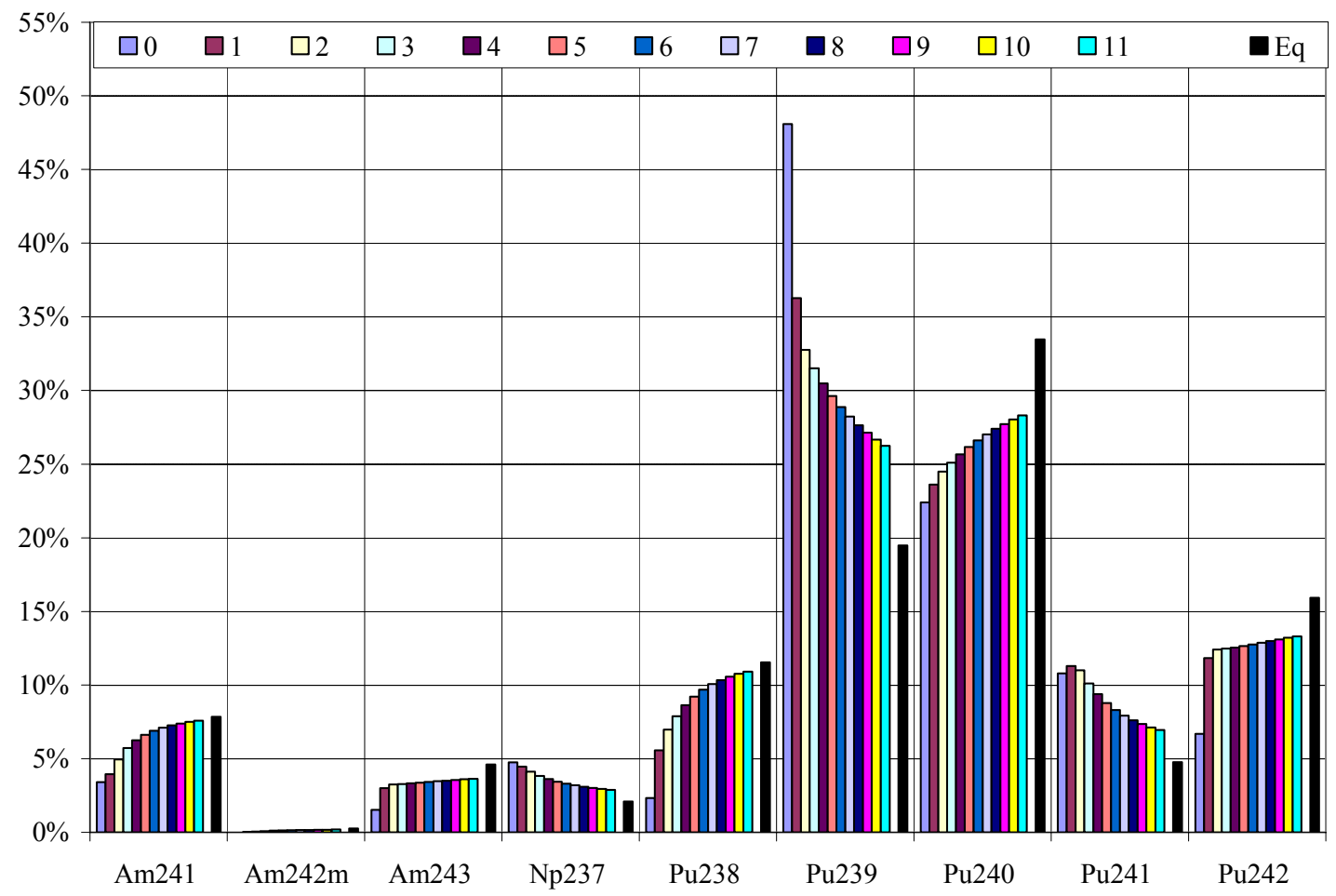

Figure 3. Charge Isotopic Compositions for the Serial Blending of Transuranics in Homogeneous IMF Assembly. 
Table 4 shows the integrated mass flow of the transuranic inventory normalized to the $\mathrm{UO}_{2}$ TRU discharge through the ten generations that were evaluated and the projected equilibrium. The direct recycle of the Generation 0 spent IMF and OTC values are included in Table 4 for comparison. All normalized values in Table 2 are relative to the value in column 2 . The results show that on average the TRU will be recycled many times. At equilibrium, the transuranic recycle rate will be more than 8 times the feed rate from the spent $\mathrm{UO}_{2}$ fuel as a result of the small fractional destruction in each pass. Approximately $75 \%(9,681 \mathrm{~g})$ of the transuranics from the spent $\mathrm{UO}_{2}$ fuel will be fissioned, $11.5 \%$ will be discharged to the waste stream as either unrecovered $\mathrm{Np}, \mathrm{Pu}$, and $\mathrm{Am}(0.9 \%)$ or as material transmutated to curium or higher actinides (10.6\%). An additional 4.7\% will decay to uranium (mostly U-234). For the true equilibrium the residual would be zero, whereas the $8.8 \%$ residual for the equilibrium in Table 4 is a result of the large extrapolation used to project the equilibrium. Additional iterations would be needed to get a more accurate estimate of the equilibrium IMF, but the current estimate is generally within $10 \%$ for total mass and individual isotopes. The results also show that after ten recycles of IMF in this serial blending strategy a larger fraction (41\%) of the TRU remains than after the direct recycle of the IMF (38\%). The total TRU waste fraction for a finite number of recycles would include the waste fraction plus the residual fraction contained in the spent IMF. For example, after the tenth generation of IMF (11 recycles), 46.6\% of the total LWR TRU processed in eleven recycle would be sent to the repository if no further recycles were completed. The TRU waste sent to the repository would be in the form of reprocessing wastes $(5.3 \%)$ and spent IMF fuel $(41.3 \%)$.

Table 4. Integrated TRU Mass Flow of Serial Blending Strategy.

\begin{tabular}{|c|c|c|c|c|c|c|}
\hline $\begin{array}{c}\text { IMF Generation } \\
\text { I (\# recycles) }\end{array}$ & $\begin{array}{c}\mathbf{U O}_{2} \\
\mathbf{T R U}^{1}\end{array}$ & Fissioned $^{2}$ & Waste $^{3}$ & Decay $^{4}$ & Residual $^{5}$ & Recycled $^{6}$ \\
\hline $\mathbf{O T C}$ & & & $100 \%$ & & & \\
\hline $\mathbf{0}(\mathbf{N}=\mathbf{1})$ & 12,896 & $55.8 \%$ & $0.7 \%$ & $0.0 \%$ & $43.5 \%$ & $99.3 \%$ \\
\hline $\mathbf{1}(\mathbf{N}=\mathbf{2})$ & 25,792 & $49.6 \%$ & $2.0 \%$ & $0.2 \%$ & $48.3 \%$ & $119.6 \%$ \\
\hline $\mathbf{2}(\mathbf{N}=\mathbf{3})$ & 38,688 & $47.1 \%$ & $2.8 \%$ & $0.3 \%$ & $49.8 \%$ & $143.6 \%$ \\
\hline $\mathbf{3}(\mathbf{N}=\mathbf{4})$ & 51,583 & $46.7 \%$ & $3.2 \%$ & $0.4 \%$ & $49.7 \%$ & $168.7 \%$ \\
\hline $\mathbf{4}(\mathbf{N}=\mathbf{5})$ & 64,479 & $47.0 \%$ & $3.6 \%$ & $0.5 \%$ & $48.8 \%$ & $193.5 \%$ \\
\hline $\mathbf{5}(\mathbf{N}=\mathbf{6})$ & 77,375 & $47.7 \%$ & $4.0 \%$ & $0.6 \%$ & $47.7 \%$ & $217.4 \%$ \\
\hline $\mathbf{6}(\mathbf{N}=7)$ & 90,271 & $48.5 \%$ & $4.3 \%$ & $0.8 \%$ & $46.5 \%$ & $240.5 \%$ \\
\hline $\mathbf{7}(\mathbf{N}=\mathbf{8})$ & 103,167 & $49.4 \%$ & $4.6 \%$ & $0.9 \%$ & $45.2 \%$ & $262.5 \%$ \\
\hline $\mathbf{8}(\mathbf{N}=\mathbf{9})$ & 116,063 & $50.3 \%$ & $4.8 \%$ & $1.0 \%$ & $43.9 \%$ & $283.6 \%$ \\
\hline $\mathbf{9}(\mathbf{N}=\mathbf{1 0})$ & 128,959 & $51.2 \%$ & $5.1 \%$ & $1.1 \%$ & $42.6 \%$ & $303.8 \%$ \\
\hline $\mathbf{1 0}(\mathbf{N}=\mathbf{1 1})$ & 141,855 & $52.2 \%$ & $5.3 \%$ & $1.2 \%$ & $41.3 \%$ & $32 \% .1 \%$ \\
\hline \hline
\end{tabular}


Table 5 shows the energy generation and discharge burnup of the IMF through the ten generations that were evaluated and the projected equilibrium. The direct recycle of the Generation 0 spent IMF and OTC values are included in Table 5 for comparison. Only a relatively small fraction of the energy, approximately $15 \%$ at equilibrium, is produced by the IMF. The discharge burnup of the IMF declines dramatically with each generation. This is a result of increased TRU loading required to achieve the target reactivity. Figure 4 shows the initial heavy metal loading in an assembly for $\mathrm{UO}_{2}$, the ten generation of IMF evaluated, the projected equilibrium IMF, and the direct recycle of the Generation 0 IMF. The discharge burnup is inversely proportional to the loading because both the assembly power and fuel residence time were fixed. For the equilibrium recycle of the IMF, the heavy metal loading of the IMF would be nearly $70 \%$ of the $\mathrm{UO}_{2}$ assembly. This is similar to the load required for the direct recycle of the Generation 0 IMF without blending. If this high loading is achievable, which may not be practical due to the high decay heat and radiation levels, the infinite recycle of $\mathrm{Np}, \mathrm{Pu}$, and $\mathrm{Am}$ in LWRs as IMF would be neutronically feasible without degradation of the assembly performance (i.e., similar power and cycle length as a typical $\mathrm{UO}_{2}$ assembly).

Table 5. Energy Generation for Serial Blending Strategy.

\begin{tabular}{|c|c|c|c|c|}
\hline $\begin{array}{c}\text { IMF Generation } \\
\text { I (\# recycles) }\end{array}$ & $\begin{array}{c}\mathbf{U O}_{2} \text { Energy }^{1} \\
\left(\mathbf{G W d} / \mathbf{M T} \mathbf{U O}_{2}\right)\end{array}$ & $\begin{array}{c}\text { IMF Energy }^{2} \\
(\text { GWd MT UO }\end{array}$ & $\begin{array}{l}\text { Total Integrated } \\
\text { Energy }^{3} \text { (GWd) }\end{array}$ & $\begin{array}{c}\text { Discharge } \\
\text { Burnup } \\
\text { (GWd/MT) }\end{array}$ \\
\hline OTC & 50.0 & 0.0 & 50.0 & $\mathrm{~N} / \mathrm{A}$ \\
\hline $0(\mathrm{~N}=1)$ & 50.0 & 7.1 & 57.1 & 553 \\
\hline $1(\mathrm{~N}=2)$ & 50.0 & 5.5 & 112.5 & 303 \\
\hline $2(\mathrm{~N}=3)$ & 50.0 & 5.3 & 167.8 & 214 \\
\hline $3(N=4)$ & 50.0 & 5.7 & 223.5 & 180 \\
\hline $4(N=5)$ & 50.0 & 6.0 & 279.5 & 159 \\
\hline $5(N=6)$ & 50.0 & 6.3 & 335.8 & 145 \\
\hline $6(N=7)$ & 50.0 & 6.6 & 392.3 & 135 \\
\hline $7(\mathrm{~N}=8)$ & 50.0 & 6.8 & 449.2 & 127 \\
\hline $8(\mathrm{~N}=9)$ & 50.0 & 7.1 & 506.2 & 121 \\
\hline $9(\mathrm{~N}=10)$ & 50.0 & 7.3 & 563.5 & 116 \\
\hline $10(\mathrm{~N}=11)$ & 50.0 & 7.5 & 620.9 & 112 \\
\hline Equilibrium & 50.0 & 8.9 & 58.9 & 72 \\
\hline G0 IMF $(\mathrm{N}=1)$ & 50.0 & 7.1 & 57.1 & 2553 \\
\hline Direct Recycle $(\mathrm{N}=2)$ & 0.0 & 0.3 & 57.4 & 67 \\
\hline
\end{tabular}

${ }^{1}$ Based on one MTIHM of $\mathrm{UO}_{2}$ fuel supplying the TRU for each generation.

${ }^{2}$ Energy generated by IMF based on $\mathrm{UO}_{2}$ feed and recycle TRU from Generation N-1.

${ }^{3}$ Total energy generated by $\mathrm{UO}_{2}$ fuel and IMF integrated through Generation $\mathrm{N}$. 


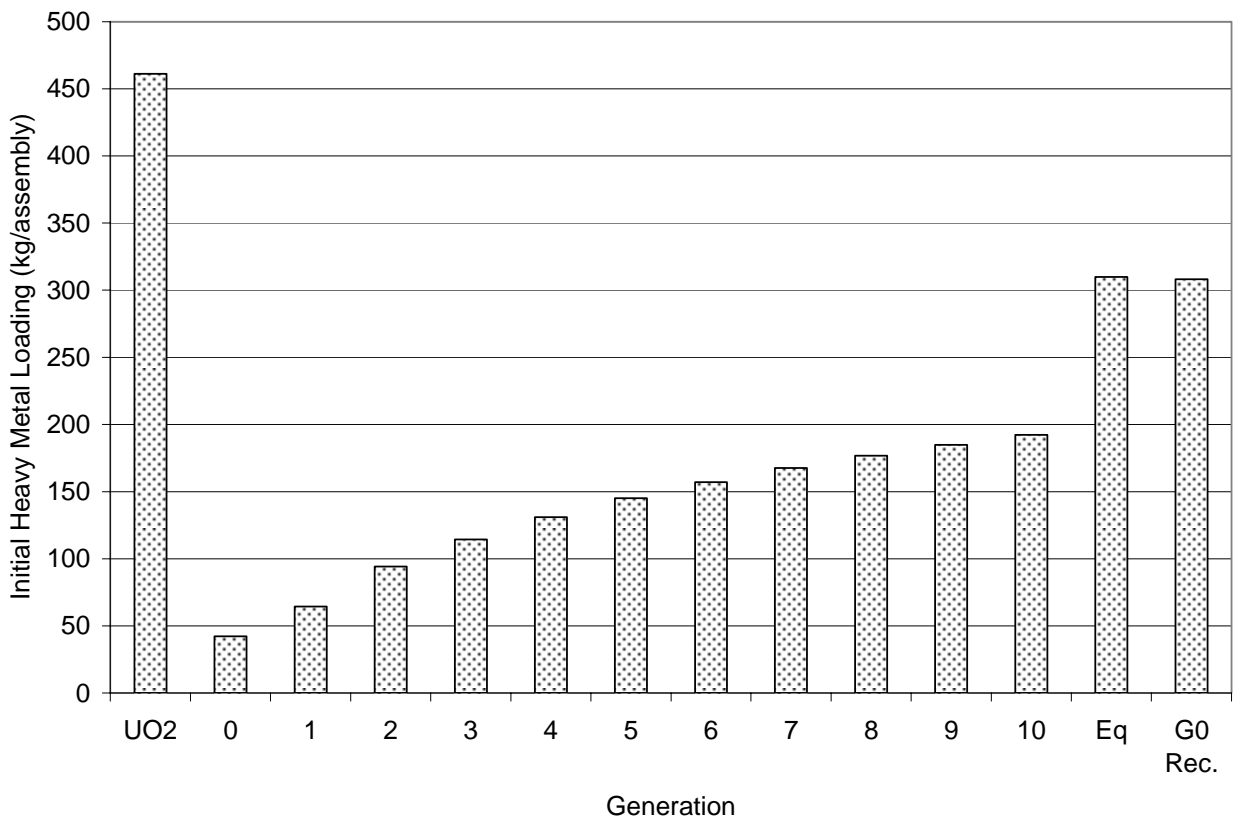

Figure 4. Heavy Metal Loading for a Standard 17x17 PWR Fuel Assembly. 


\section{II.2. Reactor Safety Considerations}

The utilization of a full-core loading of transuranic-bearing fuels will alter the reactor response to transients compared with conventional $\mathrm{UO}_{2}$. Particular concerns about the coolant void effect arise from the high transuranic loadings considered here. The hardened spectrum accompanying coolant voiding increases the neutron production/absorption $(\eta)$ in $\mathrm{Pu}-239, \mathrm{Pu}-$ 240, and $\mathrm{Pu}-241$, as well as reduces the parasitic capture in Np-237 and Am-241, potentially resulting in a positive reactivity insertion. While full-core loading of IMF assemblies is quite unlikely, reactivity parameters were calculated for an infinite-homogenous IMF core using the WIMS8 model (see Section II.1) to indicate potential problems.

Table 6 provides reactor safety information for $\mathrm{UO}_{2}$ fuel, Generation $0 \mathrm{IMF}$, and Equilibrium IMF. For $\mathrm{UO}_{2}$, the void effect is negative over the entire range of voiding due to the utilization of an undermoderated assembly design. For first recycle IMF assemblies with the same design parameters, the void effect is negative up to about $80 \%$ coolant voiding for the fresh assembly, but becomes positive as the voiding fraction continues to increase. For the discharged IMF without boron, the void effect is negative. For the equilibrium IMF, the void effect and moderator temperature coefficient (MTC) are positive at all times and boron concentrations evaluated. These are impractical values and alternative IMF assembly designs have to be considered. The Doppler temperature coefficient (DTC) remains negative for the IMF, but the magnitude is greatly reduced.

Table 6. Reactor Safety Parameters.

\begin{tabular}{|c|c|c|c|c|c|c|}
\hline & & & & $\mathrm{UO}_{2}$ & Generation 0 IMF & Equilibrium IMF \\
\hline \multirow{10}{*}{ 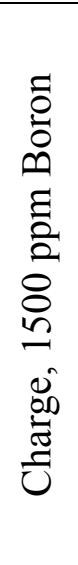 } & \multicolumn{3}{|c|}{ Boron Worth, pcm/ppm } & -6.22 & -2.43 & -0.56 \\
\hline & \multicolumn{3}{|c|}{ DTC, $\mathrm{pcm} / \mathrm{K}$} & -2.09 & -0.44 & -0.04 \\
\hline & \multicolumn{3}{|c|}{$\mathrm{MTC}, \mathrm{pcm} / \mathrm{K}$} & -3.69 & -17.71 & 56.91 \\
\hline & \multirow{7}{*}{$\begin{array}{c}\text { Void } \\
\text { Reactivity, } \\
\text { pcm }\end{array}$} & \multirow{7}{*}{ 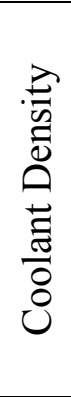 } & $100 \%$ & 0 & 0 & 0 \\
\hline & & & $80 \%$ & -462 & $-1,018$ & 3,604 \\
\hline & & & $60 \%$ & $-2,314$ & $-2,151$ & 8,629 \\
\hline & & & $40 \%$ & $-7,014$ & $-2,704$ & 15,606 \\
\hline & & & $20 \%$ & $-19,078$ & -208 & 25,472 \\
\hline & & & $10 \%$ & $-32,460$ & 3,881 & 32,394 \\
\hline & & & $1 \%$ & $-57,428$ & 9,775 & 41,674 \\
\hline \multirow{10}{*}{ 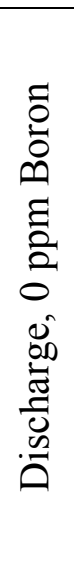 } & \multicolumn{3}{|c|}{ Boron Worth, $\mathrm{pcm} / \mathrm{ppm}$} & -9.14 & -9.85 & -0.59 \\
\hline & \multicolumn{3}{|c|}{$\mathrm{DTC}, \mathrm{pcm} / \mathrm{K}$} & -3.30 & -0.62 & -0.04 \\
\hline & \multicolumn{3}{|c|}{$\mathrm{MTC}, \mathrm{pcm} / \mathrm{K}$} & -74.87 & -56.51 & 53.99 \\
\hline & \multirow{7}{*}{$\begin{array}{c}\text { Void } \\
\text { Reactivity, } \\
\text { pcm }\end{array}$} & \multirow{7}{*}{ 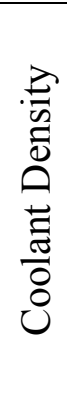 } & $100 \%$ & 0 & 0 & 0 \\
\hline & & & $80 \%$ & $-5,415$ & $-4,538$ & 3,466 \\
\hline & & & $60 \%$ & $-14,018$ & $-11,568$ & 8,540 \\
\hline & & & $40 \%$ & $-28,908$ & $-22,952$ & 15,813 \\
\hline & & & $20 \%$ & $-57,938$ & $-41,137$ & 26,311 \\
\hline & & & $10 \%$ & $-81,958$ & $-50,298$ & 33,745 \\
\hline & & & $1 \%$ & $-112,002$ & $-50,428$ & 43,769 \\
\hline
\end{tabular}


Figure 5 shows the reactivity of the fresh, once-burned, twice-burned, and thrice-burned fuel and the average at the end of cycle. The values are included for $\mathrm{UO}_{2}$, IMF through the ten generations that were evaluated, the projected equilibrium IMF, and the direct recycle of the Generation 0 spent IMF. The results show a much smaller absolute reactivity swing from fresh fuel to discharge for IMF. The boron worth for the IMF is much smaller in magnitude than for the $\mathrm{UO}_{2}$ assembly. Despite the smaller reactivity swing in absolute terms, the magnitude of the reactivity swing in terms of boron equivalent is much larger. Therefore, a much larger boron equivalent (soluble boron plus burnable poisons) concentration will be required to compensate for the burnup reactivity swing of the IMF. Additionally, the low boron worth suggests a low control rod worth, but this has not been evaluated.

It is, however, unlikely that full-core loadings of IMF assemblies considered here will be utilized in practice. Rather, a core loaded with a heterogeneous mixture of $\mathrm{UO}_{2}$ and IMF assemblies could be used to reduce the impact of the coolant voiding, soluble boron worth, MTC, and DTC effects. For the recycling campaigns with IMF considered here, the fraction of $\mathrm{UO}_{2}$ assemblies in the nuclear enterprise (from which the transuranic material originates) is $\sim 85 \%$ (see Section II.3 below).

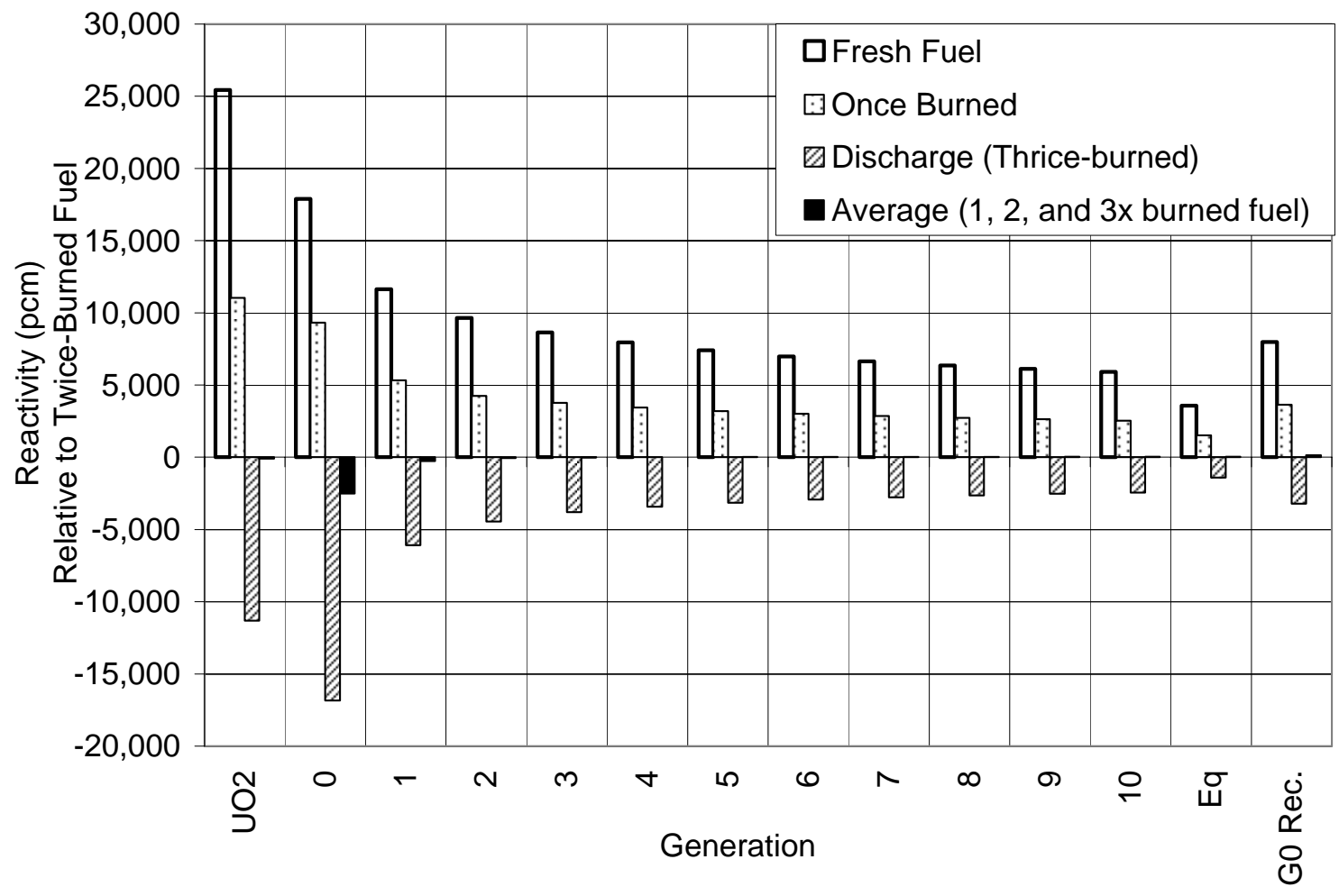

Figure 5. Effect of Coolant Voiding on Assembly $\mathbf{k}_{\infty}$. 


\section{II.3. Nuclear Enterprise Data}

In addition to the assembly-level calculations which were performed to determine the spent fuel assembly isotopics, an evaluation of the commercial nuclear enterprise and associated infrastructure requirements was performed for the LWR recycling strategies considered here. The nuclear enterprise is envisioned as consisting of a mix of reactors fueled predominantly with $\mathrm{UO}_{2}$ and IMF assemblies with recycled material. Each reactor in the enterprise could be either homogeneously loaded with a single assembly type (in which case there would be some units with a full-core loading of TRU-bearing fuel) or, as discussed above, a given reactor could be heterogeneously loaded with $\mathrm{UO}_{2}$ and recycled fuel. The latter approach would alleviate some of the difficulties associated with burning TRU-bearing fuel in reactors with safety systems designed for low-enriched uranium fuel.

For each of the recycle strategies, the material disposed in the repository consists of reprocessing wastes and directly disposed spent fuel assemblies. The relative amounts of $\mathrm{UO}_{2}$ and recycled fuel loaded in the nuclear enterprise are needed in order to properly calculate the repository heating arising from the disposed waste. For this study, an "equilibrium" enterprise was assumed, that is, just enough $\mathrm{UO}_{2}$ is burned in the system to produce the $\mathrm{Pu}+\mathrm{Np}+\mathrm{Am}$ needed to fuel all "downstream" assemblies through the $\mathrm{N}^{\text {th }}$ recycle. Effectively, all newlyfabricated $\mathrm{UO}_{2}$ in the enterprise is reprocessed, but none of the spent fuel in the "legacy waste" is utilized.

The " $\mathrm{F}_{l}$ " values provided in Table 7 are the amount of fuel (initial heavy metal) from recycle $l$ that must be reprocessed to harvest enough transuranic material to fabricate a given amount of fuel material for recycle $l+1$. So, for example, the spent fuel associated with 78.11 MTIHM UO must be reprocessed to harvest enough $\mathrm{Pu}+\mathrm{Np}+\mathrm{Am}$ to fabricate $1 \mathrm{MTIHM}$ of the first-recycle IMF. The calculation is slightly more complicated for subsequent generations of IMF using the serial blending strategy. For example, the spent fuel associated with $110.88 \mathrm{MTIHM} \mathrm{UO}_{2}$ and 0.71 MTIHM first-recycle Generation 0 IMF must be reprocessed to harvest enough $\mathrm{Pu}+\mathrm{Np}+\mathrm{Am}$ to fabricate 1 MTIHM of the second-recycle Generation $1 \mathrm{IMF}$. However, half of $\mathrm{UO}_{2}$ material is not processed during the second recycle but was in fact processed during the first recycle to produce enough material to manufacture the 0.71 MTIHM of Generation 0 IMF.

Figure 6 illustrates the fraction (by total core volume) of the various fuel types loaded in the nuclear enterprise for the recycling strategy considered here. Assuming equal power sharing between the $\mathrm{UO}_{2}$ and the IMF, the values given here provide a first-guess at the fraction of nuclear power generated by conventional $\mathrm{UO}_{2}$ and IMF. Although the assumption of equal power sharing is not necessarily a good one since the recycling strategies have not been optimized. As the number of recycles increases, the fraction of IMF varies between $11 \%$ and $15 \%$. 
Table 7. Calculated " $F$ " Values for and IMF Recycling Campaigns. $F_{l}$ is the mass of fuel from recycle 0 through $I$ (MTIHM) that must be reprocessed to produce one MTIHM of fuel material for generation $l+1$.

\begin{tabular}{|c|c|c|c|c|c|c|c|c|c|c|c|}
\hline \multirow[b]{2}{*}{$\begin{array}{c}\text { IMF Generation } \\
\text { I (\# recycles) }\end{array}$} & \multicolumn{11}{|c|}{ Reprocessed Material } \\
\hline & $\mathbf{U O}_{2}$ & $\begin{array}{c}\mathbf{0} \\
(\mathrm{N}=1)\end{array}$ & $\begin{array}{c}1 \\
(\mathrm{~N}=2)\end{array}$ & $\begin{array}{c}2 \\
(\mathrm{~N}=3)\end{array}$ & $\begin{array}{c}3 \\
(N=4)\end{array}$ & $\begin{array}{c}4 \\
(N=5)\end{array}$ & $\begin{array}{c}5 \\
(N=6)\end{array}$ & $\begin{array}{c}6 \\
(N=7)\end{array}$ & $\begin{array}{c}7 \\
(\mathrm{~N}=8)\end{array}$ & $\begin{array}{c}8 \\
(\mathbf{N}=9)\end{array}$ & $\begin{array}{c}9 \\
(N=10)\end{array}$ \\
\hline $0(N=1)$ & \begin{tabular}{|c|}
78.11 \\
$(78.11)$
\end{tabular} & & & & & & & & & & \\
\hline $1(N=2)$ & $\begin{array}{c}55.44 \\
(110.88)\end{array}$ & $\begin{array}{c}0.71 \\
(0.71)\end{array}$ & & & & & & & & & \\
\hline $2(N=3)$ & \begin{tabular}{|c|}
40.43 \\
$(121.29)$ \\
\end{tabular} & $\begin{array}{c}0 \\
(0.52) \\
\end{array}$ & \begin{tabular}{|c|}
0.73 \\
$(0.73)$ \\
\end{tabular} & & & & & & & & \\
\hline $3(N=4)$ & $\begin{array}{c}31.78 \\
(127.10) \\
\end{array}$ & $\begin{array}{c}0 \\
(0.41)\end{array}$ & $\begin{array}{c}0 \\
(0.57) \\
\end{array}$ & \begin{tabular}{|c|}
0.79 \\
$(0.79)$ \\
\end{tabular} & & & & & & & \\
\hline $4(\mathrm{~N}=5)$ & $\begin{array}{c}26.52 \\
(132.58)\end{array}$ & $\begin{array}{c}0 \\
(0.34)\end{array}$ & $\begin{array}{c}0 \\
(0.48)\end{array}$ & $\begin{array}{c}0 \\
(0.66)\end{array}$ & $\begin{array}{c}0.83 \\
(0.83)\end{array}$ & & & & & & \\
\hline $5(N=6)$ & $\begin{array}{c}23.00 \\
(137.98)\end{array}$ & $\begin{array}{c}0 \\
(0.29)\end{array}$ & $\begin{array}{c}0 \\
(0.41)\end{array}$ & $\begin{array}{c}0 \\
(0.57)\end{array}$ & $\begin{array}{c}0 \\
(0.72)\end{array}$ & $\begin{array}{c}0.87 \\
(0.87)\end{array}$ & & & & & \\
\hline $6(N=7)$ & $\begin{array}{c}20.48 \\
(143.36)\end{array}$ & $\begin{array}{c}0 \\
(0.26)\end{array}$ & $\begin{array}{c}0 \\
(0.37)\end{array}$ & $\begin{array}{c}0 \\
(0.51)\end{array}$ & $\begin{array}{c}0 \\
(0.64)\end{array}$ & $\begin{array}{c}0 \\
(0.77)\end{array}$ & $\begin{array}{c}0.89 \\
(0.89) \\
\end{array}$ & & & & \\
\hline $7(N=8)$ & $\begin{array}{c}18.60 \\
(148.80)\end{array}$ & $\begin{array}{c}0 \\
(0.24)\end{array}$ & $\begin{array}{c}0 \\
(0.34)\end{array}$ & $\begin{array}{c}0 \\
(0.46)\end{array}$ & $\begin{array}{c}0 \\
(0.59)\end{array}$ & $\begin{array}{c}0 \\
(0.70)\end{array}$ & $\begin{array}{c}0 \\
(0.81)\end{array}$ & \begin{tabular}{|c|}
0.91 \\
$(0.91)$
\end{tabular} & & & \\
\hline $8(N=9)$ & $\begin{array}{c}17.14 \\
(154.27)\end{array}$ & $\begin{array}{c}0 \\
(0.22)\end{array}$ & $\begin{array}{c}0 \\
(0.31)\end{array}$ & $\begin{array}{c}0 \\
(0.42)\end{array}$ & $\begin{array}{c}0 \\
(0.54)\end{array}$ & $\begin{array}{c}0 \\
(0.65)\end{array}$ & $\begin{array}{c}0 \\
(0.75)\end{array}$ & $\begin{array}{c}0 \\
(0.84)\end{array}$ & $\begin{array}{c}0.92 \\
(0.92) \\
\end{array}$ & & \\
\hline $9(\mathrm{~N}=10)$ & $\begin{array}{c}15.98 \\
(159.78) \\
\end{array}$ & $\begin{array}{c}0 \\
(0.20) \\
\end{array}$ & $\begin{array}{c}0 \\
(0.29) \\
\end{array}$ & $\begin{array}{c}0 \\
(0.40) \\
\end{array}$ & $\begin{array}{c}0 \\
(0.50) \\
\end{array}$ & $\begin{array}{c}0 \\
(0.60) \\
\end{array}$ & $\begin{array}{c}0 \\
(0.69) \\
\end{array}$ & $\begin{array}{c}0 \\
(0.78) \\
\end{array}$ & $\begin{array}{c}0 \\
(0.86) \\
\end{array}$ & \begin{tabular}{|c|}
0.93 \\
$(0.93)$ \\
\end{tabular} & \\
\hline $10(\mathrm{~N}=11)$ & $\begin{array}{c}15.03 \\
(165.37)\end{array}$ & $\begin{array}{c}0 \\
(0.19) \\
\end{array}$ & $\begin{array}{c}0 \\
(0.27) \\
\end{array}$ & $\begin{array}{c}0 \\
(0.37) \\
\end{array}$ & $\begin{array}{c}0 \\
(0.47) \\
\end{array}$ & $\begin{array}{c}0 \\
(0.57)\end{array}$ & $\begin{array}{c}0 \\
(0.65)\end{array}$ & $\begin{array}{c}0 \\
(0.73) \\
\end{array}$ & $\begin{array}{c}0 \\
(0.81)\end{array}$ & \begin{tabular}{|c|}
0 \\
$(0.88)$ \\
\end{tabular} & $\begin{array}{c}0.94 \\
(0.94) \\
\end{array}$ \\
\hline G0 IMF (N=1) & \begin{tabular}{|c|}
78.11 \\
$(78.11)$ \\
\end{tabular} & & & & & & & & & & \\
\hline $\begin{array}{c}\text { Direct Recycle } \\
(N=2)\end{array}$ & $\begin{array}{c}0 \\
(78.11)\end{array}$ & $\begin{array}{c}2.45 \\
(2.45)\end{array}$ & & & & & & & & & \\
\hline
\end{tabular}

Note: Values in parentheses is the total material processed to produce one MTIHM of Generation $l$. The value not in parenthesis is the quantity of material recycled during the $\mathrm{N}^{\text {th }}$ recycle.

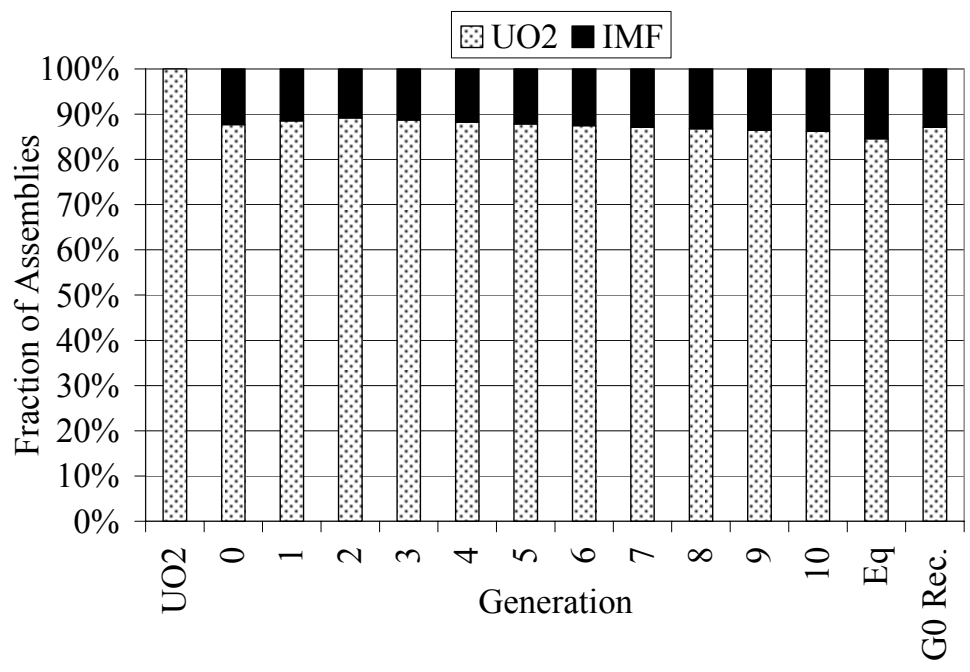

Figure 6. Distribution of Fuel Types in Each Generation of the Nuclear Enterprise. 


\section{REPOSITORY LOADING BENEFIT FROM TRANSURANIC MANAGEMENT IN LWRS}

The benefits of the recycling strategy considered here, expressed in terms of increased repository loading capacity, were obtained from thermal analyses of the repository. A detailed description of the repository thermal analyses and the consequent loading benefit resulting from multiple recycles of plutonium, neptunium, and americium in an LWR are provided in Ref. 9.

The decay heat characteristics of the disposed material, whether reprocessing wastes, fission products, or transuranics not consumed in the recycling campaign, were evaluated with the ORIGEN2 code. One group cross section data for a MOX assembly loaded in a mixed $\mathrm{UO}_{2} / \mathrm{MOX}$ core are included with the code package as a standard-use library (the so-called pwrpupu library). In order to improve the accuracy of the ORIGEN2 analysis relative to the multi-group WIMS8 results, appropriate substitute cross section data for some actinide and fission product nuclides were derived from the WIMS8 output. For all other nuclides, cross section data from ORIGEN2 pwrpupu library were utilized without modification.

The integrated decay heat from 100 to 1,250 years provides the best estimate of the contributors to the rock pillar peak temperature for the reference case. ${ }^{6}$ This is the parameter used to estimate repository.

The relative repository loading as a function of the number of recycles was evaluated based on the decay heat generated by the direct disposal of the assembly in the final (" $\mathrm{N}$ th") recycle, as well as disposal of all waste materials accumulated from spent fuel reprocessing in any previous recycles. The reprocessed waste material included all curium, $0.1 \%$ of the $\mathrm{Pu}, \mathrm{Np}$, and $\mathrm{Am}$, and all fission products except cesium, strontium, and their daughters; the Cs and Sr were assumed sent to temporary storage. In the recycling strategies, spent fuel assemblies are diverted to reprocessing and recycling rather than direct disposal in the repository. Thus, the decay heat generated by the final directly-disposed assembly (and associated reprocessing wastes) substitutes for the heat which would have been contributed by the reprocessed fuel had it been disposed directly in the repository. In order to account for this, the decay heat of the material finally disposed in the repository was normalized to the "net energy generation" of the material in the Generation $I$ assembly,

$$
B_{l}^{N e t}=F_{U_{2}} B_{U O_{2}}+\sum_{i=0}^{l-1} F_{i} B_{i}+B_{l},
$$

where $B_{i}$ is the burnup of the fuel in recycle $i$ (expressed in $\left.G W d / M T H M\right), F_{l}$ is the initial mass of fuel (MTIHM) that must be reprocessed to produce 1 MTIHM of IMF in Generation $l$, and $l+1$ is the total number of recycles practiced. Calculated values for $F_{l}$ for the IMF recycling campaigns are provided in Table 7 , above.

The repository benefit (RB) is the defined as the normalized integrated decay heat of the OTC (direct disposal of spent $\mathrm{UO}_{2}$ ) relative to the normalized integrated decay heat of the Generation N IMF and all waste produced in the manufacture of this IMF.

$$
R B=\frac{\int_{100}^{1250} D H_{U O_{2}}^{S N F}(t) d t}{B_{U O_{2}}^{N e t}} / \frac{\int_{100}^{1250}\left[f_{N} D H_{N}^{S N F}+D H_{U O_{2}}^{\text {waste }}+\sum_{i=0}^{N-1} f_{i} D H_{I M F}^{\text {waste }}\right] d t}{B_{N}^{\text {Net }}},
$$


Table 8 provides the net energy generation and repository benefit based on a number of assumptions for the IMF through the ten generations that were evaluated and the projected equilibrium. The direct recycle of the Generation 0 spent IMF and OTC values are included in Table 8 for comparison. The repository benefit calculated in a number of manners to evaluate different assumptions. Column 3 (SNF HM) quantifies the relative decay heat of the residual heavy metal in the SNF normalized to the net energy generation. This provides the relative importance of the residual heavy metal from Generation to Generation. Column 4 (HM \& SNF HM) quantifies the relative decay heat of the residual heavy metal both in the SNF and the waste stream (includes $\mathrm{Cm}$ ). This provides a measure of the effectiveness of the process at destroying the transuranics. Column 5 (FP, HM, \& SNF) quantifies the relative decay heat without and additional processing or storage of the fission products. This shows the relative repository capacity without separation of the Cs and Sr. Column 6 (Excluding Cs \& Sr in Processed Waste) quantifies the relative decay heat with the $\mathrm{Cs}$ and $\mathrm{Sr}$ removed from the waste sent to the repository. This shows the benefit of separation of the Cs and $\mathrm{Sr}$.

The results also show that serial blending would actually reduce the repository benefit for a limited number of recycles beyond the first recycle. The repository benefit is dominated by the residual TRU in the SNF for a limited number of recycles. The repository benefit is initially reduced by the serial blending because of the poisoning effect of the TRU recycled from the previous generation of IMF. This poisoning effect reduces the fractional destruction of the TRU as provided in Table 4, above. In the direct recycle, all TRU recovered from the spent $\mathrm{UO}_{2}$ fuel is irradiated to $553 \mathrm{GWd} / \mathrm{MTIHM}$. Whereas in the serial blending strategy, the TRU recovered from the spent $\mathrm{UO}_{2}$ fuel is irradiated to progressively lower discharge burnups (fractional destruction) with each subsequent generation and the net energy generation initially increases far slower and does not compensate for the reduced fractional burnup. Based on the serial blending strategy used in this study, the repository benefit remains less than a factor of two for at least ten generation (eleven recycles). Other blending ratios will be evaluated to see if the repository benefit of a limited number of recycles can be improved by the 2.1 achieved by direct recycle of the Generation 0 IMF.

If this process were repeated through a large number of generations, the fractional destruction ultimately reaches an equilibrium value, while the net energy generation continues to grow without bound. After many recycles, the reprocessing waste will dominate the integrated decay heat in the repository, which limits the repository benefit to no more than an order of magnitude for the assumed recovery fraction. The results show that an equilibrium recycle of $\mathrm{Np}, \mathrm{Pu}$, and Am in LWRs as IMF would achieve a repository benefit of between 7 (Column 5) and 10 (Column 6). 
Table 8. Net Energy Generation and Repository Benefit for IMF Recycling Campaign.

\begin{tabular}{|c|c|c|c|c|c|}
\hline \multirow[b]{2}{*}{$\begin{array}{c}\text { IMF } \\
\text { Generation } \\
\text { I (\# recycles) }\end{array}$} & \multirow[b]{2}{*}{$\begin{array}{c}\text { Net Energy } \\
\text { Generation } \\
\text { (GWd/ MTIHM) }\end{array}$} & \multicolumn{4}{|c|}{ Repository Benefit } \\
\hline & & $\begin{array}{l}\text { SNF } \\
\text { HM }^{2}\end{array}$ & $\begin{array}{c}\text { HM \& } \\
\text { SNF }^{3}\end{array}$ & $\begin{array}{c}\text { FP, HM, } \\
\text { \& } \mathbf{S N F}^{4}\end{array}$ & $\begin{array}{c}\text { Excluding Cs \& } \\
\text { Sr in Processed } \\
\text { Waste }^{5}\end{array}$ \\
\hline OTC & 50 & 1.00 & 1.00 & 1.00 & 1.00 \\
\hline $0(\mathrm{~N}=1)$ & 4,459 & 1.81 & 1.71 & 1.67 & 1.82 \\
\hline $1(\mathrm{~N}=2)$ & 6,240 & 1.62 & 1.53 & 1.50 & 1.60 \\
\hline $2(\mathrm{~N}=3)$ & 6,786 & 1.60 & 1.50 & 1.47 & 1.57 \\
\hline $3(\mathrm{~N}=4)$ & 7,102 & 1.62 & 1.50 & 1.47 & 1.58 \\
\hline $4(N=5)$ & 7,411 & 1.66 & 1.52 & 1.48 & 1.61 \\
\hline $5(N=6)$ & 7,721 & 1.71 & 1.55 & 1.51 & 1.66 \\
\hline $6(N=7)$ & 8,035 & 1.77 & 1.58 & 1.54 & 1.70 \\
\hline $7(\mathrm{~N}=8)$ & 8,354 & 1.83 & 1.62 & 1.57 & 1.76 \\
\hline $8(\mathrm{~N}=9)$ & 8,677 & 1.89 & 1.66 & 1.61 & 1.82 \\
\hline $9(\mathrm{~N}=10)$ & 9,003 & 1.95 & 1.70 & 1.64 & 1.89 \\
\hline $10(\mathrm{~N}=11)$ & 9,335 & 2.02 & 1.74 & 1.68 & 1.83 \\
\hline Equilibrium & $\infty$ & $\infty$ & 9.91 & 7.34 & 10.30 \\
\hline $\begin{array}{c}\text { G0 IMF } \\
(\mathbf{N}=1)\end{array}$ & 4,459 & 1.81 & 1.71 & 1.67 & 1.82 \\
\hline $\begin{array}{l}\text { Direct } \\
\text { Recycle } \\
(\mathbf{N}=2)\end{array}$ & 10,973 & 2.16 & 2.10 & 2.02 & 2.11 \\
\hline
\end{tabular}

${ }^{1}$ All quantities are normalized to the net energy generation, which is the integrate energy produced in making and irradiating 1 MT of Generation N IMF.

${ }^{2}$ Only residual heavy metal in the SNF is considered.

${ }^{3}$ Includes decay heat from residual heavy metal in the SNF and heavy metal material in waste stream from all previous recycles.

${ }^{4}$ Includes decay heat from HM\&SNF plus all fission products.

${ }^{5}$ Excludes cesium, strontium and their daughters from the waste stream. Cesium and strontium are assumed to be separated from waste stream. 


\section{CONCLUSIONS}

Previous studies have shown that the direct recycle of the recovered TRU from spent IMF was found to be quite limited due to the rapid burndown of the fissile plutonium. A systematic study of blending strategies (for both IMF and MOX) has been initiated and is currently ongoing.

In the present study, the potential for a continuous or infinite homogeneous recycling of plutonium, neptunium, and americium in LWRs was evaluated. A serial blending approach was investigated to determine the feasibility of continuous recycle of the IMF. The serial blending assumed that all IMF was recycled and blended with the TRU from a fixed quantity of spent $\mathrm{UO}_{2}$ fuel that has been processed. This new IMF would then be irradiated and the blending repeated. This serial blending would ultimately lead to an equilibrium IMF consuming the transuranics from a fixed inventory of $\mathrm{UO}_{2}$-fueled LWRs. The properties of the equilibrium IMF would determine the feasibility of continuous recycle. Charge and discharge isotopic vectors and mass flows were determined, and the consequent impacts on safety parameters and repository heat load were estimated for each generation of IMF and the equilibrium IMF.

The transuranic loading needed to maintain the reactor cycle length in successive recycles had to be increased beyond what seems practical from the viewpoint of safety coefficients and fuel handling parameters. This approach, however, predicts an equilibrium IMF composition and loading that is physically possible. The equilibrium IMF has an initial heavy metal loading that is approximately $70 \%$ of $\mathrm{UO}_{2}$ fuel, while the IMF produced with only $\mathrm{TRU}$ from $\mathrm{UO}_{2}$ requires a heavy metal loading that is less the $10 \%$ of $\mathrm{UO}_{2}$ fuel.

This serial blending strategy allows for more than a single recycle, but does not result in improvements in repository benefit until a very large number of recycles have been performed. The repository benefit would decline for several recycles and then grow slowly with the repository benefit remaining near 2.0 for more than ten recycles. A full range of blending ratios will be evaluated to assess the impact of blending ratio on repository benefit for a limited number of recycles.

This type of blending strategy would not be used unless part of an equilibrium recycle strategy. The repository loading benefit for the continuous or infinite recycle of the IMF was estimate to be a factor of 10 for the assumed recovery fractions, no $\mathrm{Cm}$ recycle, and $\mathrm{Cs} / \mathrm{Sr}$ separation. The impact of curium recycle will be evaluated as part of the ongoing study of blending strategies.

If the high concentration of TRU in individual fuel pins is achievable, the safety performance can be improved by heterogenous cores and/or assemblies. Serial blending would not be used to approach equilibrium because of the slow evolution of the isotopics and the large number of recycles required to approximate equilibrium performance. Reactivity support from enriched $\mathrm{UO}_{2}$ could potentially reduce the loading requirements in the IMF, which will be evaluated further. 


\section{REFERENCES}

1. Van Tuyle, G. J., et al, Candidate Approaches for an Integrated Nuclear Waste Management Strategy - Scoping Evaluations, AAA Program Report, LA-UR-01-5572 (2001).

2. Kim, T. K., Assessment of CORAIL-Pu Multi-Recycling in PWRs, Argonne National Laboratory, ANL-AAA-018, June, 2002.

3. Kim, T. K, Stillman, J. A., and Taiwo, T. A., Assessment of TRU Stabilization in PWRs, Argonne National Laboratory, ANL-AAA-020, August, 2002.

4. Stillman, J. A., Mixed-Oxide Assembly Design for Series 1 Transmutation, Argonne National Laboratory, ANL-AFCI-086, July, 2003.

5. Taiwo, T. A., Kim, T. K., and Salvatores, M., Feasibility Study of a Proliferation Resistant Fuel Cycle for LWR-Based Transmutation of Transuranics, Argonne National Laboratory, ANL-AAA-027, August, 2002.

6. Stillman, J. A., Homogeneous Recycling Strategies in LWRs for Plutonium, Neptunium, and Americium Management, Argonne National Laboratory, ANL-AFCI-124, August, 2004.

7. WIMS - A Modular Scheme for Neutronics Calculations, User's Guide for Version 8, Serco Assurance.

8. Kasemeyer, U., et al, Comparison of Pressurized Water Reactor Core Characteristics for 100\% Plutonium-Containing Loadings, Nuclear Technology, 122, April, 1998.

9. Wigeland, R. A., Bauer, T. H., Stillman, J. A., and Kim, T. K., Repository Impact of Spent Fuel Recycling Using Water-Moderated Thermal Spectrum Reactors, Argonne National Laboratory, Report to the ANTT Sub-Committee of NERAC, April, 2004. 